\title{
ドック受診者のアポリポタンパクの検討
}

$\begin{array}{lllll}\text { 神山 清志, 中西 久江, 牧田 京子, 斉藤 } & \text { 和徳 } \\ \text { 宮村 隆三, 松谷 清一, 石川 哲也, 早川 } & \text { 隆 }\end{array}$

〈目的〉近年脂質代謝異常の検索にアポタンパク 測定が重要視されている。アポタンパクはリポタンパ クの構成成分であり, 脂質の連搬代謝の一端を担う重 要な役割をもつ。その測定は, SRID 法が主体であった が, 最近では,アポA-I, A-II, B, C-II, C-III, $\mathrm{E}$ の 6 種について TIA 法が開発され, 自動分折器を用 いて短時間にかつ正確に定量することが可能となって いる。しかし，アポ A-I，A-II，Bは，抗原量が多い 為あらかじめ検体を希釈してからでなくては測定でき ず，希釈の手間，同一ラインでの分折の不可等問題が 認められていた。今回我々は検体希釈を必要としない 第一化学薬品の新しいアポタンパク測定試薬, アポオ ート・2「第一」を用い, アポ A-I，A-II，B，C-II, C-III, E及び, B/A-I , A- I /A-II, C-II/C-III, E/ C-IIIの比について正常值を設定し, 従来用いられてい たアポタンパク TIA 研究により設定された第一化学 社内データとの比較を試み, 若干の知見を得たので報 告する。

〈方法, 対象〉アポ A-I , A-II, B は,アポオート・ 2「第一」。C-II，C-III，Eは従来のアポオート「第一」 を用い, 日立 7150 にて測定した。旧法と新法のパラメ ーター上の違いは, 新法では抗原抗体 complex の量が 多い為主波長 $340 \mathrm{~nm}$ では感度がオーバーしてしまう ので, $600 \mathrm{~nm}$ を用いていることが挙げられる。対象は 浦和市医師会成人病検診センタードック受診者 888 名 より, TCH $220 \mathrm{mg} / \mathrm{d} l$, TG $150 \mathrm{mg} / \mathrm{d} l$ 以下の条件を 満たす正脂血者 635 名を抽出し, 全体, 男女, 年齢別 （30６0 歳台）について臼井法にて正常值を設定した。

〈結 果〉求められた正常值は, アポ A-I, A-II, $\mathrm{B}$ においては, 第一化学社内デー夕との間に有意差は ほとんど認められなかった。C-II, C-III, Eでは, 当 センターの方が若干ではあるが, 高目の設定となった。 アポタンパク比においては, B/A-I が若干低めでは
あったが，他に有意差は見られなかった。年齢別正常 值は,アポ B, C-II, C-III， E，B/A-I が加齢による 上昇傾向を示しアポ $\mathrm{A}-\mathrm{I}$ が 60 代で低下したが，他に 大きな変化は認められなかった。

〈考察〉アポA-I，A-II，Bは，異なる試薬との 比較であったが, 求められた正常值に有意差は認めら れなかった。アポC-II，C-III，Eにおいては，同一試 薬の比較であったにかかわらず，当センターの正常值 の方が高めに設定されてしまった。理由として，第一 化学の正常值は統計は同じ臼井法で行われているが, 対象が多施設，多機種である為と考えられる。年齢別 正常值においては, 加齢によりアポ $\mathrm{B}, \mathrm{E}, \mathrm{C}$ 群 $\mathrm{B} / \mathrm{A}$ I 比が高くなる傾向を示し, 全体の正常值の上限值よ り高い所まで設定值がおよんでいる。これは加齢によ り動脈硬化性疾患が増えるというデー夕の裏付けにな ると思われる。正常值を設定するにあたり，対象は正 脂血に限定したが,アポBでは, 約 $10 \%$ ア正常值を越 えていた。また, HDL-C が $40 \mathrm{mg} / \mathrm{d} l$ 以上と正常であ っても, 約 $5 \%$ のアポ-I が正常下限值を切ってい た。このことから，たとえ TCH, HDL-C, TG 值が正 常範囲内にあったとしても, 脂質代謝は正常に行われ ていると $100 \%$ \%断言はできないであろう。

〈まとめ〉 アポリアポタンパクの測定は, 今までの $\mathrm{TCH}, \mathrm{HDL}-\mathrm{C}, \mathrm{TG}$ を主とした脂質検查値の盲点を力 バーするといった意味で臨床的に意義の高い項目であ ろう。また，脂質の血中存在型のリポタンパクに主点 を置き，その代謝を知る上では，必要不可決なものと 思われる。また, 測定操作も, アポオート・2「第一」 を用いることにより他の項目と同一条件で行うことが できるようになった。以上のことから，ドック受診者 のアポタンパク測定は予防医学の面からも重要な項目 と思われる。

\section{A Study of Serum Apolipoproteins in MHTS 浦和市医師会成人病検診センター}

